\title{
The Role of International Cooperation in Demarcation of Territorial Boundaries in International Law and Procedures
}

\author{
Mohammad Saberrad $^{1} \&$ Seyed Ghasem Zamani ${ }^{2}$ \\ ${ }^{1} \mathrm{PhD}$ student in the field of Public International Law at Imam Reza international university, Mashhad, Iran \\ ${ }^{2}$ Faculty member of Allameh Tabatabai University, Teheran, Iran \\ Correspondence: Seyed Ghasem Zamani, Faculty member of Allameh Tabatabai University, Teheran, Iran. \\ E-mail: drghzamani@gmail.com
}

Received: April 27, 2016

doi:10.5539/mas.v10n9p81
Accepted: May 12, 2016

Online Published: June 7, 2016

URL: http://dx.doi.org/10.5539/mas.v10n9p81

\begin{abstract}
Non-judicial developments in the field of boundary issues, with the aim of achieving stability and preserve it, move toward the ideal of international community. The ideal is to maintain international peace, order and security. Developments and advances are in the service of this ideal and countries take steps in this direction with responsibility than before and with believe in integrity of international peace, order and security, and apply technical and human progresses in this way. International organizations and countries, as the main subjects of international law, with understanding adverse consequences of instability, use all the tools necessary to achieve this goal and non-judicial developments occurring in delimitation of international territorial boundaries, are in line with this excellent goal. Today, countries cooperate wider than past in different ways and in all fields including boundary issues. Deep understanding toward the importance of international peace, order and security and legal belief to necessity of such cooperation, undoubtedly have facilitate today direction. Of course, the role of international institutions and organizations was very dramatic in developing such belief.
\end{abstract}

Keywords: territorial boundaries, delimitation, demarcation, boundary maintenance and protection, boundary consolidation

\section{Introduction}

Until a period of time, force and power has been the main source of legitimacy. In fact, type of system international legal system would cause it, but a will based on international system composition change and it's systematic in form of nations system and United Nations Charter was followed (Cassese, 2005).

The present international community is characterized with two basic elements that make it distinct from classical period and begin since 1914 in World War II. One of them is international organization network that reaches to its highest level in United Nations organization and the other is multiple increases of countries to this community (Stone, 1956, p. 198). With increase of countries, the need for stability, peace and order increases in international community. Boundary issues with their inherent sensitivity, affect greatly on the issue of international peace and security, and countries with understanding this cooperate wider in different boundary issues. In this study, the role of international cooperation in delimitation of international boundaries is examined.

\section{a. Third Party role in delimitation of territorial boundaries}

One of the non-judicial developments in delimitation of territorial boundaries is important third party role in border and territorial issues between countries. One of the third parties who play role in this field, are international organizations. Meantime the United Nations organization plays an important role as the most important international organization. The United Nations organization is a complex and extensive organization and parts of it that play the main role to solve territorial and boundary conflicts are the Security Council, general assembly, a committee about announcement of independence to people and independent countries (Special Committee on decolonization) and international Court of Justice. Certainly, the importance of states meetings within the United Nations organization should not be forgotten that leads to important cooperation for solving boundary and territorial conflicts (Prescott, 1996).

Authorities of general assembly in this field are retained in 10,12, 14 articles of the charter that relate to questions, issues or situations, which must be negotiated or discussed or there will be recommended actions. 
Authorities of Security Council have determined in this field by Chapter VI of the Charter, which title is peaceful resolving of conflicts.

The Security Council can also act when a conflict endanger peace maintenance and international security and issue binding statements according to Chapter VII of the charter (Boudjema, 2013).

In a particular case, the Security Council demarcated the boundary of Iraq-Kuwait by forming a commission. This process, is the first the demarcation of an international boundary, which was conducted with the request of the UN Security Council (Pinther, Robertson, William, Shrestha, \& Srebro, 2013).

ICJ has the most prominent role as judicial element of United Nation organizations in resolving territorial and boundary disputes between countries and is a considerable size of court decisions on demarcation of territorial boundaries between countries and examination of this role requires a separate and detailed study to examine the role of Court and judicial developments concerning the demarcation territorial boundaries. Court rules are very important in the field of boundaries and territorial situations and their topic are objective affairs that inevitably give a general credit and pervasive effect to court decisions, but UN Secretary General as the highest official status in United Nations organization plays a prominent role in resolving territorial and boundary conflicts between countries and even their demarcation. An example of the successful efforts of the UN Secretary General can be seen in implementation of ICJ judgment in territorial and maritime boundary conflict between Cameroon and Nigeria (Le Febvre, 2014).

Along with United Nations organization, regional organizations also play role in resolving boundary and territorial conflicts between countries. One of these organizations, OAU, was Africa unity organization, which is converted to African Union (AU) now. Also Arab union in this field states in $5^{\text {th }}$ article that if a dispute occurs among member states that does not include independence, sovereignty or territorial integrity of a country, two parties ask the Council to resolve this dispute, then Council decision must be effective and binding (Mucombo, 2013).

OAS (Organization of American States) also is active in the field of resolving territorial and boundary disputes between countries and for example encouraged file reference of arbitration of Spain king (Honduras against Nicaragua) and Land, Island and Maritimr Frontier dispute between El Salvador and Honduras to ICJ for adjudication, and noted this issue to both parties in its instruction. Sometimes, third party role help countries, with providing information or funds to demarcate boundaries (Merrills, 2000).

\section{b. Serious and prominent role play of boundary commissions}

International boundaries, as dividing lines of neighbor's territorial sovereignty, have bilateral importance. This means that, procedures related to boundaries require active participation or consent of the two neighboring countries. International Boundary Commissions, today play an important role, yet in some cases play role in procedures of development, modifying and maintaining an international boundary to avoid conflicts between neighboring countries and underlie more cooperation within the border (Donaldson, 2012).

Boundary commission consists of representatives of two neighboring countries. A boundary commission may be temporary and composed to resolve a certain boundary or it may be permanent and once the boundary have been determined take some responsibilities for boundary management. Authority and composition of committees mainly is originated from two relevant countries, but exceptionally committee may composed by a third party like United Nations organization. In this case, the representatives of third parties are present. Since the demarcation performance has technical and technological characteristic, it must be deposited to the commission, which is composed of boundary engineers. Determination of demarcation commission must be clarified in delimitation treaty or agreement (Adler, 1995).

Today, this is usual that a boundary be ruled through a shared boundary commission, that its role is to ensure order and security along the border and monitor the adherence to treaty or agreement, based on which boundary has been developed (Adler, 1995).

There are examples of permanent boundary commissions, which have responsibilities other than demarcation and maintenance of boundary. Some of them consider issues such as management of border crossing water, environmental management, security management, availability and a few of general cross-border cooperation (Donaldson, 2012).

At the end, this discussion is referred to as an example of successful boundary commission, which could be a model of cooperation, coordination, goodwill and beneficial effects for two countries causing it: Mixed boundary commission of Canada/America. Generally, duties of the Commission can be classified in three categories: Operational, consultative and maintenance (O'Sullivan, 2001). 


\section{c. Establishment and increase of collaboration between adjacent countries}

Generally, two dominant views exist on the role of boundaries (especially in development literature of border areas): The first, boundary is considered as a dividing line and second, boundary is considered as contact area. Closed boundaries prevent from formation of institutional, political and social systems in border region and also they are an obstacle for free flow of information and exacerbate social complexities of market. But in boundary viewpoint as a contact area, border region as an area that businesses and other social networks can transcend boundary lines, develop new opportunities and advantages, and role of the boundary in itself convert from an obstacle to a bridge or in other words converts from a wall to a valuable source. Today, globalization by effect on the ability of national governments to control their borders unconditionally, practically has converted the nationstates from conflict lines to communication and interaction areas. Experiences of countries and different border regions of the world such as the United States and Mexico boundary, Germany and Poland boundary, China and Hong Kong boundary, South Africa and Masaryk boundary are evidence for this claim. Some border experts emphasize that during the early stages of negotiations, problematic areas should be abandoned by both Commission members and when possible, they should focus on those parts of the boundary that are not subject to major conflicts. Then, practical solutions, which have been found for less problematic situations can resolve more challenging areas, by developing trust among the members of commissions. Some border experts about sensitive and strongly disputed areas recommend that some practical steps must be taken to reach an agreement and as one of the possible steps, raise exchange of the country (OSCE, 2011).

When the countries with the best intentions are committed to implement shared demarcation, they fight with the nature of vague description of delimitation. If both involved countries develop political will to undertake demarcation of their boundaries, some satisfactory solutions can be found (Ramtane, 2012).

Boundary demarcation and maintenance or boundary reaffirmation can be successful only when it is managed by peaceful means and patience to negotiate and with a common technical understanding and cooperation (Mucombo, 2013).

When two countries undertake fieldwork to demarcate or maintenance of boundary, it is important that the parties work together. This means that two parties must have a common and uniform understanding of local landscapes and also means that local populations of the border will see cooperation of the commission and this leads to more respect toward commission in local border associations (Donaldson, 2012).

\section{d. The important role of research and education in today's boundary issues}

Today, study on boundary issues, facilitates and helps processes of boundary issues. Of these cases, we can mention to the efforts of the African Union Border Program (AUBP). AUBP provides good techniques and procedures which are collected by guide experts working in this field and helps to the development of personnel technical capacities and will discuss with them about suitable procedure and necessary experience on this program, and promote study about durable demarcation solutions and obtained findings (Ramtane, 2012).

Research requires a complement called training, that significant efforts have been seen in this field. For example, among mentioned objectives of AUBP, specific development of education and research programs, increasing awareness about AUBP and its work, increasing awareness about sensitivity of boundary issues have been addressed (Diarrah, 2012). As a new initiative, the African Union Border Program has targeted the systematic change of prevailing negative sentiment about the African boundaries as obstacles, toward the acceptance of boundaries as bridges with inherent positive roles and functions (Diarrah, 2012).

Among the valuable research works in the field of boundary issues, we can also refer to "Euro Boundaries", which is a multi-purpose project aimed to gathering European boundaries information collection (Alsayel, 2010).

European boundaries project was established in 2005 by Euro Geographic members, which aim is obtaining information over national boundaries with the highest available accuracy and also involves standardizing legal procedures, collecting and preparing of such boundary for entire Europe (Daniel, 2013).

Another aspect of training is role play in boundary issues and this field is training and developing workshops. Training of personnel, especially in order to use modern technology, technically responds the skill of boundary commissions members that can reduce the need for foreign experts (Daniel, 2013).

Other important developments in the field of boundary issues, is serious role play of research in this field. One of the activists in the field of boundary research is IBRU. IBRU is a part of Geography department of Durham University in England that since its establishment as international boundaries research unit in 1989, was the main research center and a leader in construction of international boundaries and resolving conflicts and do this through providing services for public and private sectors. Today, IBRU conduct a shared work in the field of 
international law and geography, by geographical study of borders and boundaries in 21 century (https://www. dur.ac.uk/ibru).

\section{e. Use the uti possidetis principal in non-colonial situations}

Regarding decomposition of Socialist Federative Republic of Yugoslavia (SFRY), Badinter Commission, was developed as a private committee to examine the situation in the Federation and applied uti possidetis principal for boundary delimitation of new emerging countries. In fact, applying this colonial principal was discussed in a non-colonial situation, but promotion criteria of previous internal boundaries to the situation of international boundaries in SFRY territory in countries procedures and United Nations organization organs was accepted despite the discussions (Vidmar, 2010). Badinter commission to apply the ut ipossidetis principal in the case ahead, appealed to a piece of 20 border conflict case paragraph in his third opinion, in which the court considered the uti possidetis principal as a general principal that is related to the phenomenon of obtaining independence wherever and its aim is to prevent fratricide conflicts (2001).

Justification the first principle of uti possidetis, first in Latin America and then in Africa, was that it followed by minimizing internal, regional or international threats against peace and security. This was obtained by appealing to territorial stability in critical moment of transition to independence and exactly the same motivations are behind principle identification, outside the colonial context alone, in Yugoslavia, where similar risks arising from disintegration of the country are apparent (Shaw, 1997).

In another case, promotion of internal boundaries, to the status of international boundaries has been interpreted in documents found in CIS as a formal acceptance, that in some parts of the former Soviet Union republics, uti possidetis was a valid solution to solve territorial conflicts between them. This interpretation, that new international limitation in the territory of the Soviet Union was the result of applying uti possidetis principle, is even apparent in the report of Europe Union Fact-Finding Mission in order to investigate armed conflict in Georgia in 2008. This report points out Badinter opinion to show that this principle is applicable beyond the decolonization process, although it will be met with some criticism (Vidmar, 2010).

\section{Conclusion}

In the past, the factor of boundary delimitation was power. Today, due to the prohibition of threat to use of force, agreement factor is in the center of international boundaries delimitation. Outside of international tribunals delimitation of territorial boundaries has undergone some changes in some areas. Today, countries with a sense of fixation to international community, cooperate with each other and demarcate their boundaries and in this context:

Today, the third party, has more prominent role in boundary issues that in the past. The third party, including global or regional organizations, another country or even official and influential international character, tries to facilitate and resolve conflicts and finally achieving to a stable boundary, since a stable boundary causes consolidation of international peace and security.In this way, even some countries and international organizations provide a considerable pecuniary, logistical and technical assistance to very distant countries and even in another continent beyond their geographical area, which indicates formation of a legal belief (opinio Juris) among countries on the basis that international peace, order and security cannot be separated, but they are integrated and violation and threat, damages its totality and its consequences affect all members of the international community. We're on a boat and our security depends on the security of others. Therefore, with belief on their responsibility in this regard they do their best to maintain the security of this integrated system.

Today, common boundary commissions are working with different forms and various tasks between countries. Countries have found that border is a place for bilateral agreement and bilateral agreement, in bilateral commissions and in some cases with third party participation as tripartite, requires shared operations in various fields. Today's commissions are representative of involved States and a factor to reduce political load on high political and governmental officials, and many problems can be solved within them. Common commissions of adjacent countries, provide peace and stability.

As it was mentioned above, today agreement is a determining factor in international boundaries. Such agreements are expressed in various forms and collaboration of countries is now the highest factor to ensure respect for existing boundaries and agreement. Collaboration of countries in border issues, in fact indicates their accountability for a higher purpose: Maintenance of international peace, order and security.

Regarding the important role of research and education in present border areas, can be satisfied with this sentence: Knowledge on all issues, including boundary issues, is useful and this knowledge requires explanation and clarification of issues in all its aspects and it must be transferred to users in different ways. We can say that 
here science is a mean achieve the goal that has been repeated in above mentioned cases: Peace, order and security.

But in the case of uti possidetis principal application in non-colonial situations, it must be explained that the reason for putting this case on non-judicial developments, is that International Court of Justice has applied this principal only in post-colonial situations in its approach and even in the dispute of Qatar against Bahrain despite the reference to this principle, the court refused to apply it in a post-mandate situation (2001). The reason that badinter commission and subsequently Europe Fact-Finding Mission on the Georgian crisis have invoked this principal in a non- colonial situation must be searched again in the need for peace and security. They choose to apply this principal and use its fine results to maintain stability, order and peace in a critical situation and in a region prone to racial and religious bloody conflicts and in a very sensitive time. At the end, it must be said that somehow the origin and purpose of all these developments, is to develop stability in order to achieve peace, order and security.

\section{References}

Adler, R. (1995). Boundary and Territory Briefing: Positioning and Mapping International Land Boundaries. International Boundary Research Unit, University of Durham, UK.

African Union Border Programme (AUBP) (2012, November; 2014, Agust). Delimitation and Demarcation of Boundaries in Africa (2nd Ed.). The Workshop held Under the Overall Guidance and Leadership of the AUBP. Adis Ababa, Ethiopia.

Alsayel, M. Y. (2010). Towards Standardizing International Boundary Determination and Quality Control Consequences on Surveying and Mapping. Von der facultat Fur Bauingenieurwesen und Geodasie der Gottfried Wilhelm Leibniz Universitat Hannover Zur Erlangung des Grades DOKTOR-INGENIEUR (Dring), Hannover.

Boudjema, M. (2013). Peaceful Settlement of International Boundary Disputes, Cited in Delimitation and Demarcation of Boundaries in Africa, African Union Border Programme (AUBP), Adis Ababa.

Cassese, A. (2005). International law (2nd Ed.). Oxford University Press.

Daniel, T. (2013). Lexicon of Boundary Making. Cited in Delimitation and Demarcation of Boundaries in Africa, African Union Border Programme (AUBP), Adis Ababa.

Diarrah, A. (2012). An Overview of the African Border Programme. Cited in Delimitation and Demarcation of Boundaries in Africa, African Union Border Programme (AUBP), Adis Ababa.

Donaldson, J. (2012). Boundary Commission: Creating Effective Structures and Practices. Cited in Delimitation and Demarcation of Boundaries in Africa, African Union Border Programme (AUBP), Adis Ababa.

Donaldson, J. (2012). Executive Summary. Cited in Delimitation and Demarcation of Boundaries in Africa, African Union Border Programme (AUBP), Adis Ababa.

Le Febvre, R. K. (2014). Interests and Identities in peace Negotiations: Nigeria, Cameroon and the Bakassi Peninsula. African Social Science Review, 6(1), Article. 6.

Merrills, J. G. (2000). Commentray: The International Court of Justice and the Adjudication of Territorial and Boundary Disputes. Leiden Journal of International Law, 13, Issue. 4.

Mucombo, J. E. (2013). Demarcation and Maintenance of the International Boundaries of Mozambique, Cited in Delimitation and Demarcation of Boundaries in Africa, African Union Border Programme (AUBP), Adis Ababa.

OSCE (2011, May 31 to June 1). Applied Issues in International Land Boundary Delimitation/Demarcation Practices. A Seminar Organized by the OSCE Borders Team in Co-operation with the Lithuanian OSCE Chairmanship, Vilnius, Lithuania.

O'Sullivan, M. (2001). The Work and Value of International Boundary Commissions: The Canadian/American Experience. Boundary and Security Bulletin, 9(3).

Pinther, M., Robertson, A., William, S. M., Shrestha, B. N., \& Srebro, H. (2013). International Boundary Making, FIG Publication (International Federation of Surveyors).

Prescott, V. (1996). Contributions of the United Nations to solving Boundary and Territorial Dispute 1945-1995. Political Geography, 15(3/4).

Ramtane, L. (2012). Delimitation and Demarcation of Boundaries in Africa, Cited in Union Border Programme 
(AUBP), Adis Ababa.

Shaw, M. N. (1997). Peoples, Territorialism and Boundaries. European Journal of International Law, 8(3).

Stone, J. (1956). What Price Effectiveness? (p. 198). American Society of International Proceedings.

Toure, A. (2013). Post Conflict Demarcation of African Boundaries: The Cameroon- Nigeria Experience. Cited in Delimitation and Demarcation of Boundaries in Africa, African Union Border Programme (AUBP), Adis Ababa.

Vidmar, J. (2010). Confining New International Borders in the Practice of Post-1990 State Creations, Zaorv 70, Max-Plank-Institut fur auslandisches offentliches Recht und Volkerrecht.

\section{Copyrights}

Copyright for this article is retained by the author(s), with first publication rights granted to the journal.

This is an open-access article distributed under the terms and conditions of the Creative Commons Attribution license (http://creativecommons.org/licenses/by/3.0/). 